\title{
The tendency of word usage in the modern Russian and Kazakhstan media
}

\author{
Zhanar Kiynova - Sandugash Sansyzbaeva - Ainash Ahmetzhanova - Dariga \\ Kapasova - Indira Muratbayeva
}

DOI: $10.18355 / X L .2018 .11 .02 .54$

\begin{abstract}
The article discusses the features of the use of modern language Slavonic words in newspapers. On the material, collected from the newspaper subcorpus of Russian National Corpus, active language describes the processes that are most clearly reflected in the media. On the basis of the analyzed context, the author draws conclusions about the main trends of the modern use of somatic Slavonic words and stylistically marked verbs describing the same type of situation. There are given the examples of figurative rethinking of biblical terms as a result of various associations, reflecting the value ideas of a modern democratic society.
\end{abstract}

Key words: modern Russian and Kazakhstan media, Slavonic words, stylistically labeled archaic words, Biblicisms, Russian national corpus

\section{Introduction}

Anthropocentric paradigms of scientific knowledge have led to the need for greater attention to communication, which is especially important for linguistics that studies the language of human positions, producing information and perceiving it. Architectonics of contemporary Russian discourse is characterized by new forms of communication and new genres in everyday, public, professional and business communication, as well as a shift to the periphery of the artistic discourse.

In modern life, the means of mass media (hereinafter - the media) play a dominant role, as they reflect the interests and tastes of the most diverse languages of social groups and have a strong and all-encompassing influence on the society and its institutions. The language of the media is dynamic, agile, and closely linked to the extra-linguistic situation in the country, and therefore is always in the field of research. It is known that at all times, the leading the media function of the media is informational, but the democratization of the newspaper discourse in a dynamically changing reality leads to the use of its other functions, such as creative function and function of cultural memory. Newspaper as the most dynamic form of print media reflects the socio-political and socio-cultural situation in the country in its entirety; journalistic style is used in the newspaper, with all the variety of newspaper genres, includes elements of virtually all other functional styles of modern Russian language; journalistic style before other functional styles captures the language / speech changes, i.e. reflects active processes in the modern language at all levels.

The modern newspaper text is characterized by the polemical, high degree of evaluativity and persuasiveness. The researchers also noted increased informative start, activation of personal tendencies, approval of dialogueness as the fundamental quality of newspaper speech. All this suggests that in the newspaper text is implemented the function of impacting. The title is not only an active means of attracting the reader's attention but also influences him by means of expressive language and speech. Therefore, the impact of the function causes an acute need of publicistics in the expressive-evaluative tools, which are borrowed from the literary language. First of all, publicistics is used to express the assessment of the existing, ready-made material: phraseological units dating back to the biblical texts, slogans of old and new rhetoric: "Vozlyubi blizhnego svoego" (Love your neighbor); "Da ne oskudeet ruka dayuschego" (Let not scanty the hand of the giver); "Mne vozmezdie - i 
az vozdam" (I will receive retribution - and I shall repay);"Parlament rabotaet na iznos" (The Parliament is working on the wear and tear); "Mostyi sozhzhenyi i komanda - tolko vpered i ni shagu nazad" (Bridges are burned, and the crew keep only forward and not a step back); "Proletarii vseh stran, soedinyaytes!" (Workers of all countries, unite!).

Imagery system, clear expression and a profound moral content of biblical phraseology and Slavonic words composed of stable combinations can serve as a powerful impact potential. The analysis of modern language newspapers shows that Slavonic words are most often used in the headline as it stands out from the informative text and draws the readers' attention.

\section{Literature Review}

"High", book, or traditional poetic vocabulary, that reflects the moral and spiritual values and traditions of the people (агнеи [agnets] (lamb), внимать [vnimat] (hear), вещзать [veschat] (tell), вопиять [vopiyat] (understand), грядущий [gryaduschii] (future), врата [vrata] (gates), страж [strazh] (guardian), таинство [tainstvo] (mystery), стезя [stezya] (way), глава [glava] (head), грясти [gryasti] (approach), деяние [deyanie] (deed), шествовать [shestvovat] (parade) and etc.), has been widely involved in the newspaper usage. "Modern reality creates a wide variety of situations in which the use of stylistic Slavonic words seems communicatively caused not only in the spiritual language, but in different functional styles of language" (Nefedieva, 2014).

The trend of the use of passive vocabulary fund is observed since the end of the XX century and is related to these extra-linguistic factors such as the democratization of society, the spiritual "rebirth" of the society, which meant a return to religious sources and as a result, updating of moral principles. Analyzing the originality of language newspaper in the post-Soviet period E.V. Kahorina (2000) writes that "... in accordance with the tradition of an old stable journalistic vocabulary is widely used not in a denotative, but in an expressive function. Compare expressive compliance with the new category of "president": царь Борис (tsar Boris), царь Бориска (tasr Boriska), Борис кровавый (Bloody Boris), мученик (martyr). State high-level officials today are called dignitaries, rallies, and strikes - turmoil and nation-wide council, official correspondence - petitions. Particularly, press, newspapers are characterized by the use of words with national, patriotic orientation" (Kahorina, 2000).

Slavonic words in the modern Russian language constitute a vast reservoir of archaic vocabulary, therefore are preserved in the composition of set expressions. For example, the word "преткновение" [pretknovenie] (stumble, obstacle) is derived from a verb "претъкнутися" [pretknutisya] meaning "to stumble", survived only as part of a set expression "камень преткновения", meaning "obstacle, difficulty, which is faced by everyone". " As part of such combinations as глас вопиющего в пустыне, древо познания добра и зла, власти предержащие (voice of one crying in the wilderness, the tree of knowledge of good and evil, the powers that be), there are also Slavonic words which went out of use. All these combinations have arisen when the words преткновение [pretknovenie] (stumble), глас [glas] (voice), древо [drevo] (tree), предержати [prederzhati] (to stumble) and etc. were not yet been out-dated, but combining them with other words, as a result of frequent repetition, have entrenched in the language. Such combinations in the modern language are used primarily for styling the biblical language. The use of biblical words projecting the idea of holiness, sacredness of everything that has a connection to the Bible and the religious cult. This opens up the possibility for influencing theo native speakers through an appeal to the authority of the Bible and the biblical word. For example, in modern Russian and Kazakh newspapers there are such titles as Ne zhdat mannyi nebesnoy" (Do not wait for manna from heaven); "Solomonovo reshenie"

XLinguae, Volume 11, Issue 2, April 2018, ISSN 1337-8384, eISSN 2453-711X 
(Solomonic solution), "Rabotayut denno i noschno" (working day and night); "Glas naroda' (voice of the People) and others. However, they can occur not only in the culturally significant contexts for native speakers, but also in a variety of newspaper articles, in which cultural and religious content may be absent. For example, in the context zaznaystvo bludnogo syina (conceit of the Prodigal Son). This is related to different types of cases and transformations (semantic, lexical, syntactic, contamination, paronomasia phraseological and stylistic confusions) traditional set expressions. For example, the idiom-biblicism "Ne hlebom edinyim" (Not by bread alone) was subjected to different lexical transformations: "Ne syirom edinyim" (Not by cheese alone), "Ne hlopkom edinyim" (Not by cotton alone), "Ne boykotom edinyim" (Not by boycott alone), "Ne neftyu edinoy" (Not by oil alone), etc. In this way, the transformation of the sublime content into the subjective-personal, low content.

\section{Research Methodology}

Slavonic words as book words, having sublime and solemn color, brighter realize their emotional and expressive potential in the language of contemporary newspapers, mainly in the headlines - the main structural elements of newspaper texts, realizing their basic function - affecting. In our view, the use of Slavonic words in headlines of newspaper articles due to its actual content: "Flagman vyisshey shkolyi - na puti $v$ gryaduschee"- "The flagship of high school - on the way to the future" (Kazahstanskaya Pravda, 2009).

Here the reader's attention is drawn to the book word грядущеe [gryadushee] (future) with a solemn color, which in modern everyday life speech is an alternative designation of the future. Apparently, the content of the article itself, which sets out the prospects for the development of the main university of the country, motivated the use of stylistically marked Slavism грядущеeе [gryadushee] (future), semantic evolution is determined by its close connection with biblical themes. Thus, analyzing the cases of the use of the canonical use of the words гряду, грядущий [gryadushii] (future) into the biblical texts, it can be assumed that it originally called the action taking place now, right in front of your eyes, but the modern consciousness interprets this action as the approaching future. "The gradual temporal rethinking of the future is influenced by idiomatization - regular correlation of the word with a certain type of situations and based on the ideas: a) "movement" (prototypical lexical semantics), and b) the "real" (prototypical grammatical semantics), allows this word to ask special insight into the future - as a "movement now," as a time of active, intruding into the present, carrying with them significant events "(Yakovleva, 1998, p. 60). This dual interpretation is associated with a particular subject area description: the modern consciousness, the word грядет is clearly contrasted is as "future", "present". In our view, the header title reflects the content of the article itself, as the word грядущиии [gryadushii] (future), above all, means coming, having at the same time some important event-and hence the space-time semantics. On the contrary, future in the modern language may be used with respect to subject names: my future husband, our future flat.

A particular interest comprise the headlines with the word apadz [grad] (town) (lacking full vocalism, such as градъ [grad] (town), злато [zlato] (gold), древо [drevo] (tree), брег [breg] (shore), вpama [vrata] (gates) and etc., which finally came out of active use rather late - in the second half of the XIX century. However, the roots of these words remained as a part of the derivatives and compound words: Волгоград, безбрежный, обезглавить, древесина (Volgograd, boundless, decapitate, wood). They, unlike their Russianisms-synonyms, are characterized by a developed system of mobile metaphoric and symbolic meanings, so have large expressive possibilities. As such headlines of newspaper articles as: "Krasuysya, grad 
Petra" - Shine, city of Peter" (AiF, 2003); "Grad vozdvignet zodchiy" - "A town will be build by an architect" (Kazakhstanskaya Pravda, 2005).

They are coloured by special solemnity and sublimity. Firstly, the stylistic markedness of the words with lack of full vocalism in the pair град-город, the city makes it commonly used in the "high" contexts imbued with an aura of greatness and limitations. For example, in the name of the central and most important from a political point of view, cities that, one way or another, have been associated with the names of prominent historical figures: Петроград, Ленинград, Сталинград, Целиноград (Petrograd, Leningrad, Stalingrad, Teslinograd).

Second, even in the ancient language of the values of these words are clearly differentiated: град [grad] (town) had the meaning of 'крепость, кремль, укрепление' (castle, citadel, fortification), and the word город (city) - had the meaning 'поселение людей' (the settlement of people). Third, attention was paid to its compatibility with the verb "воздвигнуть" [vozdvignut] (to build) (which also has Slavic origin, where the prefix -воз has inceptiveness meaning). This is quite natural, because stylistically marked the word zpad cannot be used with a neutral verb cmpoumb, the use of which is justified in the context type to build a house, build a shed, and etc. In modern Russian the verb воздвигать / воздвигнуть [vozdvigat, vozdvignut] has the meaning - 'coopydumb, nocmpoumb' (to build). Meanwhile, the modern dictionaries distinguish the word воздвигать [vozdvigat] as a special semantic component, pointing to the qualitative characteristics of action and object of the action 'cтроить что-либо высокое, большое; сооружать, созидать, возводить' (to build something tall, large; to build, to create, to erect) (Big academy dictionary of russian, 2005, p. 54). In the Old Russian language the word воздвигать had more complex semantic structure, and it had a value, designated as the specific actions and abstract. Dictionary of Russian XI-XVII centuries notes the initial values, denoting physical properties of 'поднять вверх, придать более высокое положение'; 'помочь встать, поднять на ноги (лежавшего, упавшего)'; 'соорудить, построить'; 'восстановить, воссоздать' ('to lift up, to give a higher position'; 'to help to stand up, to get to on feet (lying, fallen)'; 'to construct, to build'; 'to restore, to recreate') (Dictionary of russian of the 11-17 th centuries, 1975, p. 282283).

In the newspaper context the word воздвигать describes not only the same type of situation, combining with the words: памятник, монумент, постамент, храм, cmamyя (monument, pedestal, temple, statue):

Table 1: Contextual use of the word "to erect"

\begin{tabular}{|c|c|}
\hline Russian & English \\
\hline $\begin{array}{l}\text { «Вчера под вечер информационные } \\
\text { агентства } \\
\text { общерашили } \\
\text { Поклонноность горе якобы планируется } \\
\text { воздвигнуть памятник Сталину» } \\
\text { (Rodkin, 2005); } \\
\text { «П мнению экспертов, намерение } \\
\text { воздвигнуть статую Галилея в } \\
\text { самом сердце Ватикана является } \\
\text { попыткой } \text { Святого } \\
\text { примириться Престола } \\
\text { сообществом». } \\
\text { (Zorina, 2008). }\end{array}$ & $\begin{array}{l}\text { "Yesterday evening the news agencies } \\
\text { have stunned the public: to Victory } \\
\text { Day at Poklonnaya Hill was allegedly } \\
\text { planned erecting a monument to } \\
\text { Stalin" } \\
\text { (Rodkin, 2005); } \\
\text { "According to experts, the intention to } \\
\text { erect a statue of Galileo in the heart } \\
\text { of the Vatican is an attempt of Holy } \\
\text { Seeto to reconcile with the scientific } \\
\text { community." } \\
\text { (Zorina, 2008). } \\
\text { (Direct translation into English) }\end{array}$ \\
\hline
\end{tabular}

XLinguae, Volume 11, Issue 2, April 2018, ISSN 1337-8384, eISSN 2453-711X 689 
This expressiveness is achieved by combining a diverse vocabulary, resulting in the formation unusual combination of high words with neutral or stylistically reduced, so conscious stylistic errors are in the newspaper text norm:

Table 2: Contextual use of the word "to build "

\begin{tabular}{|c|c|}
\hline Russian & English \\
\hline $\begin{array}{l}\text { «Да и на омском стадионе «Красная } \\
\text { звезда», если закончить реконструкцию } \\
\text { и воздвигнуть трибуны-времянки, } \\
\text { можно coбрать солидную аудиторию» } \\
\text { (Lysenkov, 2011); } \\
\text { «Заместитель мэра в ответном письме } \\
\text { подтвердил, что земельный участок, на } \\
\text { котором собираются воздвигнуть } \\
\text { гараж и здание, оформлен на среднюю } \\
\text { общеобразовательную школу № } 591 \text { и } \\
\text { по договору безвозмездного срочного } \\
\text { пользования эксплуатировать школу и } \\
\text { прилегающую территорию можно } \\
\text { только в у учебно-воспитательных } \\
\text { целях» } \\
\text { (Romashova, 2005). }\end{array}$ & $\begin{array}{l}\text { "In case the reconstruction will be } \\
\text { completed and will be erected a } \\
\text { makeshift grandstand at Omsk } \\
\text { stadium "Red Star", it is possible to } \\
\text { assemble a solid audience" } \\
\text { (Lysenkov, 2011); } \\
\text { "The deputy mayor in his reply } \\
\text { confirmed that the land on which he } \\
\text { is going to build the garage and } \\
\text { building, is registered on the } \\
\text { secondary school № } 591 \text { and the } \\
\text { contract for gratuitous use to operate } \\
\text { the school and the surrounding area } \\
\text { only in educational purposes" } \\
\text { (Romashova, 2005). } \\
\text { (Direct translation into English) }\end{array}$ \\
\hline
\end{tabular}

The verb 'зреть' [zryet] (to see) in its primordial, archaic meaning of 'see, look' in the language of today's newspaper obtains emotional-evaluative and ironic tone:

Table 3: Contextual use of the word "look"

\begin{tabular}{|c|c|}
\hline Russian & English \\
\hline $\begin{array}{l}\text { «Алексей Леонидович } \\
\text { стратегически, он давно уже зрит на } \\
\text { десятилетия вперед» } \\
\text { (Рavlov, 2007); } \\
\text { «Село Гиши хаотично разметалось } \\
\text { домами на плоскогорьях. Красота, } \\
\text { коли зреть с вершин, неописуемая! } \\
\text { Подошел пьяненький мужичок: } \\
\text { «Сфотографируй } \\
\text { корреспондент». } \\
\text { (Varsegov, 2003). }\end{array}$ & $\begin{array}{l}\text { "Alexei Leonidovich thinks } \\
\text { strategically, he is already looking to } \\
\text { the decades ahead" } \\
\text { (Pavlov, 2007); } \\
\text { "The village Gishi has randomly } \\
\text { scattered houses on the plateau. If you } \\
\text { look from the mountain top, the } \\
\text { beauty is indescribable! A drunk man } \\
\text { came by: "Would you take a picture of } \\
\text { me, reporter." } \\
\text { (Varsegov, 2003). } \\
\text { (Direct translation into English) }\end{array}$ \\
\hline
\end{tabular}

Slavonic word 'глас' [glas] (voice) was one of the most common and prevalent in the use of quantitative Russism голос. This is due to the fact that the word 'глас' [glas] (voice) has several meanings portable 'внушение, зов, веление какого-либо внутреннего чувства, инстинкт, побуждения' (suggestion, call, call of any of the internal sense, instinct, motivation), for example, глас долга, истины, дружбб,, души, страстей (call of duty, truth, friendship, soul, passion) etc., 'звучание музыкальных инструментов' (sounding musical instrument), for example, глас свирели (the voice of the flute). Set expression 'глас народа' ('voice of the people') becomes relevant in the period of perestroika, publicity, and democracy, so actively used in the meaning 'мнение, суждение, призыв' (opinion, judgment, appeal) not only in the headlines, «Глас народа» («Завтра», 15.08.2008), but also in contexts describing the political events: 
Table 4: Contextual use of the word "voice"

\begin{tabular}{|c|c|}
\hline Russian & English \\
\hline $\begin{array}{l}\text { «Глас народа Кого выбирают } \\
\text { украинцы. } \\
\text { Последний социологический опрос } \\
\text { населения Украины на тему выборов } \\
\text { провел киевский центр «Третий } \\
\text { сектор». } \\
\text { (Рetrushov, 2009); } \\
\text { «Оказалось, прокуратура услышала } \\
\text { глас народа, чиновники - нет». } \\
\text { (Рatrusheva, 2010); } \\
\text { «Но глас народный был услышан } \\
\text { лишь в наступившем году» } \\
\text { (Кochugov, 2011). }\end{array}$ & $\begin{array}{l}\text { "The voice of the people. Whom } \\
\text { Ukrainians choose. } \\
\text { The last opinion poll of the Ukrainian } \\
\text { population on elections was held by } \\
\text { Kiev Center "Third sector". } \\
\text { (Petrushov, 2009); } \\
\text { "It turned out the prosecutor's office } \\
\text { heard the voice of the people, while } \\
\text { officials did not." } \\
\text { (Patrusheva, 2010); } \\
\text { "But people's voice was heard only in } \\
\text { the coming year" } \\
\text { (Kochugov, 2011). } \\
\text { (Direct translation into English) }\end{array}$ \\
\hline
\end{tabular}

The semantic and stylistic originality of the expression глас народа is manifested in its pathos, expression, enhancing the stylistic tone, expression of civil position, which makes this combination commonly used in the context of social-political content mainly in the opposition press and national newspapers of patriotic orientation:

Table 5: Contextual use of the expression "voice of the people"

\begin{tabular}{|c|c|}
\hline Russian & English \\
\hline $\begin{array}{l}\text { «Комиссия создана для того, чтобы } \\
\text { чиновники слышали глас народа и } \\
\text { информировали общественность о } \\
\text { проделанной работе». } \\
\text { (Yanchenkova, 2008); } \\
\text { «Вы ссылаетесь на мнение народа, } \\
\text { которому якобы опротивел Союз } \\
\text { кинематографистов. Но откуда вам } \\
\text { известен глас народа? Численное } \\
\text { преимущество пока старого союза». } \\
\text { (Zaozerskaya \& Hermann, 2010). }\end{array}$ & $\begin{array}{l}\text { "The Commission was established in } \\
\text { order to hear the voice of the people, } \\
\text { and inform the public about the work } \\
\text { done." } \\
\text { (Yanchenkova, 2008); } \\
\text { "You refer to the opinion of the people } \\
\text { who supposedly loathed the Union of } \\
\text { Cinematographers. But how do you } \\
\text { know the opinion of the people? The } \\
\text { numerical advantage has the old } \\
\text { Union". } \\
\text { (Zaozerskaya \& Hermann, 2010). } \\
\text { (Direct translation into English) }\end{array}$ \\
\hline
\end{tabular}

Speaking about the functioning of the high bookish vocabulary in newspaper texts, E.V. Kahorina (2000) notes that "they are being used in a new stylistic background. Inflow of this vocabulary is opposed to the more powerful, the power of the language of the modern newspaper stream vernacular language environment, forming pointed reduced stylistic background language of newspaper ... The word 'держава' [derzhava] (power) is not simple, and superior to the word 'zосударство' (state) as gives it the shade of силь, славы, могущества, величия. This is an old Slavonic term is able to excite in a man exalted feelings and emotions. Once in the newspaper text, the word держава loses its high stylistic status. Neutral and lower contexts give rise to a new compatibility, derivatives and synonymy: угробить державу, слаборазвитая сверхдержава, хилая держава, талонная держава, державка (ruin power, undeveloped superpower, frail power, talon power, small power). Thus, in a series of synonyms империя - сверхдержава - держава - государство - 
страна (superpower - power - state - country) the word 'держава' aims to take the place of a neutral member of the series "(Kahorina, 2000, p. 71).

The modern newspaper and journalistic speech is characterized by a peculiar combination of the spoken words with high or bookish words, due to a combination of the informative standard and expression, as well as the openness of media for the penetration of foreign style elements, particularly conversational ones. At the same time, these words are no longer opposed to each other in terms of stylistic distinction, the priority here obtains expressive-evaluative element of their semantics. Slavonic words getting into the newspaper text, not only lost their high stylistic status but also are mixed with stylistically contrasted, spoken words. Compare:

Table 6: Contextual use of the the words expressing parts of a body of the person

\begin{tabular}{|c|c|}
\hline Russian & English \\
\hline $\begin{array}{l}\text { «Он, мурлыча какой-то } \\
\text { диатонический мукам, втыкал иголки } \\
\text { в самые различные места моего } \\
\text { анемичного тела: в живот, в уши, в } \\
\text { ланиты, в перси, в чресла и лядвеш" } \\
\text { (Meshkov \& Snegirev, 2007). }\end{array}$ & $\begin{array}{l}\text { "He, humming about some diatonic } \\
\text { sufferings, and was stucking needles } \\
\text { into various places of anemicmy body: } \\
\text { in the abdomen, in the ears, in the } \\
\text { cheeks, to the breast, to the loins and } \\
\text { thigh" } \\
\text { (Meshkov \& Snegirev, 2007). } \\
\text { (Direct translation into English) }\end{array}$ \\
\hline
\end{tabular}

This combination of different by style elements in the language of today's newspapers should also be attributed to semantic processes taking place in the lexicon of modern times. Of course, marked by high archaisms oчu [ochi] (eyes), ycma [usta] (mouth), чело [chelo] (forehead), чрево [chrevo] (womb) and etc., in the newspaper texts are combined with reduced stylistically neutral words, resulting in losing high marker within the text, but not in the language.

"The expansion of the presentation on the newspapers pages problems are created conditions for the interpenetration of styles, which contributed to the movement of lexical resources from one style to another. In connection with a new drection of journalists on "live voice element of society", rather than the construction of a special political language, as it was in the past, the modern press incorporates a variety of forms of verbal communication and reflects the speech practices of many social groups, collectives, leading to coexistence and active cooperation in the language of modern media is extremely diverse language resources, gravitating as well as "high, but also a reduced" stylistic poles. It defines a relatively high 'mutual' permittivity of different, including "distant" language subsystems and high speed turnover of linguistic resources circulating in the media" (Monina 2009).

\section{Results and Discussions}

As the material, retrieved from of the Russian National Corpus (hereinafter - RNC), shows trends in contemporary usage, as well as evolutionary and dynamic processes taking place in the modern Russian language are most clearly reflected in the case of newspaper texts. Our observations on the material of the newspaper texts of RNC show that Slavonic words used in modern language newspapers are characterized by two trends: first, the frequency in the context of a typical, well-established combinability of words; secondly, the use of non-traditional combinations of words in order of ironic, contrasting and metaphorical description of objects and phenomena.

Indeed, examples of the traditional use of Slavonic words are scarce in the language of modern newspapers, on the other hand, there is observed the use of non-traditional combinations, formed on the basis of structural and semantic transformation of an established combination карающяая рука (punishing hand). Figurative and 
metaphorical reinterpretation of Slavonic word 'длань' creates its new, not typical compatibility with a variety of words that actualizes its use for irony, sarcasm, and allegory:

Table 7: Figurative use of a word "hand"

\begin{tabular}{|c|c|}
\hline & \\
\hline $\begin{array}{l}\text { «Когда он стал представлять } \\
\text { правоохранительные органы как } \\
\text { карающую длань сил добра, это еще } \\
\text { больше насторожила» } \\
\text { (Mikheyev, 2006); } \\
\text { «Пусть эта спасающая длань растает в } \\
\text { воздухе, как улыбка чеширского кота, } \\
\text { но главное сделано - прожит еще один } \\
\text { день» } \\
\text { (Ноw astrology was born? 2002); } \\
\text { «Хорошо бы все это перенести в наш } \\
\text { день, а в прошлом оставить длинные } \\
\text { очереди, руководящую длань обкома, } \\
\text { выборы одного депутата из одного } \\
\text { кандидата» (Zhuravlеv, 2000). } \\
\text { «Стоило школам } \\
\text { зарабатывать деньги, как немедленно } \\
\text { длань казначейства была наложена на } \\
\text { эти скромные средства» } \\
\text { (Үатburg, 2005); } \\
\text { «Посмотрите опросы общественного } \\
\text { мнения в западных странах, куда не } \\
\text { простерлась длань кПсС, - и там } \\
\text { политические партии замыкают список } \\
\text { общественных институтов, которым } \\
\text { доверяют население» } \\
\text { (Іgnаtоv, 2005). }\end{array}$ & $\begin{array}{l}\text { "When he began to represent the law } \\
\text { enforcement agencies as a hand of } \\
\text { vengeance of good forces, it became } \\
\text { even more alarming" } \\
\text { (Mikheyev, 2006); } \\
\text { "Let this saving hand meltin the air } \\
\text { like the Cheshire cat's smile, but the } \\
\text { main thing is done - another day is } \\
\text { gone" } \\
\text { (How astrology was born? 2002); } \\
\text { "It would be good to move it all in } \\
\text { our day, and to leave in the past the } \\
\text { long queues, guiding hand of the } \\
\text { regional committee, the election of } \\
\text { one deputy from one of the } \\
\text { candidate" } \\
\text { (Zhuravlev, 2000). } \\
\text { "As soon as schools have learnt to } \\
\text { make money, hand of the Treasury } \\
\text { has been immediately imposed on } \\
\text { these modest funds" } \\
\text { (Yamburg, 2005); } \\
\text { "Look to opinion polls in Western } \\
\text { countries, where the hand of the } \\
\text { Communist Party did not reach, } \\
\text { there political parties close the list of } \\
\text { public institutions that are trusted by } \\
\text { the population" } \\
\text { (Ignatov, 2005). } \\
\text { (Direct translation into English) }\end{array}$ \\
\hline
\end{tabular}

These contexts are related to the spiritual sphere of human life, that is, we are talking about "high" moral matters and public foundations. Meanwhile, in the newspaper subcorpus of RNC are more frequent contexts based on stylistic contrast: Such collaboration and the combination of stylistically diverse vocabulary enhance the expressive-evaluative element in the language of the media, due to the tendency to subjectivity of the stated information. The use of Slavonic word 'длань' in another expressive function is due to the description of social phenomena in modern society The following examples from the newspaper corpus of RNC show that such somatic Slavonic words, as oчu [ochi] (eyes), ycma [usta] (mouth), ланиты [lanity] (cheeks), чело [chelo] (forehead), etc. are preferably used to express ironically mocking lines:

Table 8: Figurative use of the the words expressing parts of a body of the person

\begin{tabular}{|l|l|}
\hline Russian & English \\
\hline $\begin{array}{l}\text { «На поле полдня поработаешь - очи } \\
\text { набухнут и слипаются» }\end{array}$ & $\begin{array}{l}\text { When you work on the field for half a } \\
\text { day - the eyes swell and stick together" }\end{array}$ \\
\hline
\end{tabular}

XLinguae, Volume 11, Issue 2, April 2018, ISSN 1337-8384, eISSN 2453-711X 


\begin{tabular}{|c|c|}
\hline $\begin{array}{l}\text { (Lvova, 2006); } \\
\text { «Плюби меня, раба Божьего (имя), } \\
\text { очи мои, руки мои, кудри мои, } \\
\text { поступь борзую, лицо белое, сердце } \\
\text { смелое» } \\
\text { (Кuzina, 2006); } \\
\text { «Вставляя в уста того или иного } \\
\text { героя матерное слово, я не } \\
\text { стремлюсь шокировать публику, это } \\
\text { всего лишь изобразительное } \\
\text { средство» } \\
\text { (Egorsheva, 2006); } \\
\text { «Bот он склонился, умыл чело, } \\
\text { зачерпнул воду, понес домой, } \\
\text { наплевав на упреждения здешних } \\
\text { экологов, что на «Маяке» опять что- } \\
\text { то лопнуло и радиация в Тече опять } \\
\text { зашкаливает!» } \\
\text { (Varsegov, 2006); }\end{array}$ & $\begin{array}{l}\text { (Lvova, 2006); } \\
\text { "Love me, servant of God (name), my } \\
\text { eyes, my hands, my curls, impudent } \\
\text { walk, white face, courageous heart" } \\
\text { (Kuzina, 2006); } \\
\text { "Inserting a swearword into the } \\
\text { mouth of a hero, I'm not trying to } \\
\text { shock the audience, it's just a visual } \\
\text { tool" } \\
\text { (Egorsheva, 2006); } \\
\text { "He has bent, washed his forehead, } \\
\text { scooped up water, and carried it home, } \\
\text { spitting on preemption of local } \\
\text { environmentalists that on "Mayak" has } \\
\text { again snapped something and radiation } \\
\text { at the Tech had increased again!" } \\
\text { (Varsegov, 2006); } \\
\text { (Direct translation into English) }\end{array}$ \\
\hline
\end{tabular}

Stylistically marked archaisms 'очи', 'уста', 'чело', etc., combined in a newspaper with neutral contexts and stylistically reduced words, losing its high stylistic status, as a result of which there is a new compatibility of words like: очи набухнут, умыл чело, вставляя в уста (eyes swell, washed his forehead, inserting into the mouth) and etc. Meanwhile, the "stylistic colouring of the archaisms 'очи' and 'чело' in the system of modern literary language is defined and constant, although it can be used in a speech for different purposes; the ability of these words give the statement a satirical coloring, which is caused by their stylistic properties as their ability to colour it in high rhetorical tone. ... Thus, for the emergence of ironic, humorous tone of speech to express satire mocking attitude to the subject of the speech with words 'очи', 'чело', there is needed a "clash" of archaisms with other by stylistic nature words, for example, with conversational or colloquial vocabulary. And to create a "high" rhetorical color combination should be the same with the same type of archaisms, high lexis. But it does not mean, that we change the stylistic coloring of the archaisms every time" (Kozhin, Krylova \& Odintsov, 1982).

In our view, the orientation of modern journalists "for live speech element of society" has led to the interaction of heterogeneous language means - as "high" or "reduced", while "spiritually marked words" may occur in a completely neutral, moreover, stylistically reduced contexts. Compare:

\section{Table 9: Contextual use of the word "face"}

\begin{tabular}{|l|l|}
\hline Russian & English \\
\hline «В.В. Жириновский, заместитель & "V. Zhirinovsky, Deputy Chairman of \\
председателя Государственной думы & the State Duma. Reader - a public \\
Читатель - общественному деятелю & figure of all or none. Merry face of \\
или всех - или никого. Развеселый & presidential assistant Igor Shuvalov \\
лик помощника президента Игоря & and horrible sense of his statements \\
Шувалова и кошмарный смысл его & just baffle" \\
заявления просто ошарашивают» & (Example of worthy leaving, 2007). \\
(Ехаmple of worthy leaving, 2007). & (Direct translation into English) \\
\hline
\end{tabular}

Here the compatibility of words is damaged: лик [lik] (face) - "high" word originally signifying the images of saints on the icons, and later - poeticism, is used mainly in the elevated, ceremonial contexts, and cannot be combined with the adjective 
развесельй (cheerful). The stylistic dissonance or a mixture of styles - a phenomenon typical of the modern newspaper language, "high" words lose their stylistic status, resulting in enhanced expressive-evaluative element and realize the function of affecting the readers.

It is quite logical that the fact that in the language of newspapers are most vividly and adequately traced all the dynamic processes taking place in the modern language, as in a mirror, is reflected the "life" of modern society, dictating priorities in the use of language means. Word 'чрево' meaning 'womb' is used in various figurative meanings. Compare:

\section{Table 10: Contextual use of the word "belly"}

\begin{tabular}{|c|c|}
\hline Russian & English \\
\hline 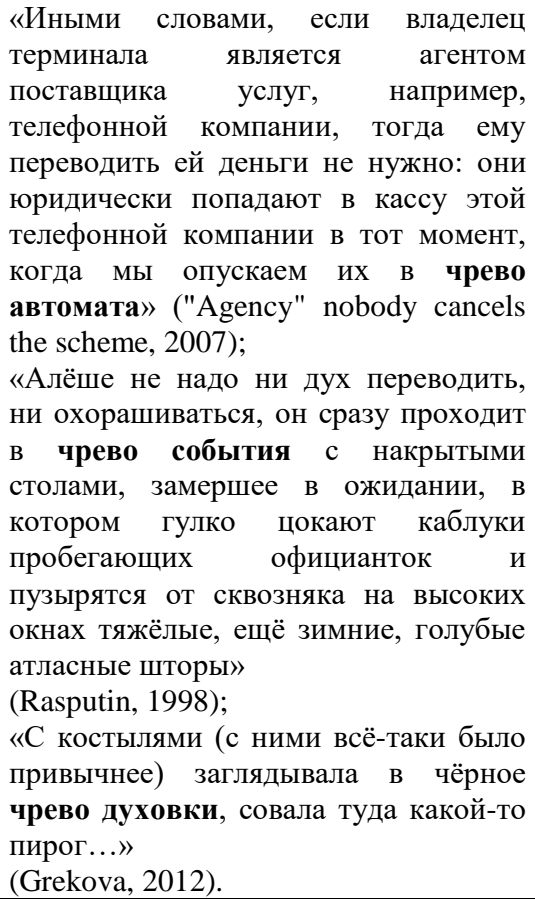 & $\begin{array}{l}\text { "In other words, if the terminal owner } \\
\text { is an agent of the service provider, } \\
\text { such as a telephone company, then he } \\
\text { transfer him money is not necessary: } \\
\text { they legally get to the cashier of the } \\
\text { telephone company at the time when } \\
\text { we drop them in the bottom of the } \\
\text { machine" } \\
\text { ("Agency" nobody cancels the scheme, } \\
\text { 2007); } \\
\text { "For Alesha is not necessary to take a } \\
\text { breath or plume, it immediately goes } \\
\text { into the heart of the event with set } \\
\text { tables, frozen in anticipation, in which } \\
\text { loudly clatter heels of running } \\
\text { waitresses and on the high windows } \\
\text { tremble from wind heavy, winter, blue } \\
\text { satin curtains" } \\
\text { (Rasputin, 1998); } \\
\text { «On crutches (with them it was more } \\
\text { habitual) looked into the black bottom } \\
\text { of the oven, popped back some cake } \\
\text {..." } \\
\text { (Grekova, 2012). } \\
\text { (Direct translation into English) }\end{array}$ \\
\hline
\end{tabular}

As can be seen from the above examples, somatic Slavonic word чрево [chrevo] (womb), which was used in the ancient language only in relation to man and associated with life (жена его чревата, чревная болезнь, etc..), in the modern language is attached to objects, concepts and events and describes what is inside, in the very center of something.

The most informative picture of the functioning of words with lack of full vocalism древо in the modern language is represented in the corpus of newspaper texts of RNC. So, modern and unconventional use of the word древо [drevo] (tree) is widely found in news contexts, due to social value of language means in journalism and use of occasional formations. Thus, the functioning of the word 'древо' within the meaning of 'genealogy, family tree' is connected with the individual author use to refer to specific entities, realities, and events: 
Table 11: Contextual use of the word "tree"

\begin{tabular}{|c|c|}
\hline Russian & English \\
\hline «Один из них - «Древо Тихоцких», & "One of them - "The family tree of \\
\hline повествует о генеалогии славного & Tihotsky" tells the story \\
\hline рода Тихоцких, чей дом (ныне музей) & Tihotsky genealogy, whose house (now \\
\hline и принял у себя 5-ю Всероссийскую & a museum) has hosted the 5th All- \\
\hline генеалогическую выставку» & Russian genealogical exhibition" \\
\hline (Ponamarev, 2007); & (Ponamarev, 2007); \\
\hline «Я считаю, что наше древо Дуровых & hat our tree of Durovs is \\
\hline $\begin{array}{l}\text { своими ветвями переплетается»), - } \\
\text { сказал нам Лев Константинович» } \\
\text { (Khrustalyova, 2007); }\end{array}$ & $\begin{array}{l}\text { intertwined by its branches," - told us, } \\
\text { Lev Konstantinovich". } \\
\text { (Khrustalyova, 2007); }\end{array}$ \\
\hline $\begin{array}{l}\text { «И тут впору рисовать } \\
\text { генеалогическое древо чемпионов } \\
\text { первого полусреднего веса» } \\
\text { (Korobotov, 2007); }\end{array}$ & $\begin{array}{l}\text { "Here it is suitable to draw a } \\
\text { genealogic tree of champions of first } \\
\text { welterweight". } \\
\text { (Korobotov, 2007); }\end{array}$ \\
\hline $\begin{array}{l}\text { «Впрочем, древо получилось все } \\
\text { равно впечатляюшее: }\end{array}$ & $\begin{array}{l}\text { "However, the tree still turned out to } \\
\text { be impressive: there are brother and }\end{array}$ \\
\hline $\begin{array}{l}\text { сестрой, и сын с женой, и } \\
\text { племянники, и, конечно, родители» }\end{array}$ & $\begin{array}{l}\text { sister, son and his wife, nephews, and, } \\
\text { of course, the parents' }\end{array}$ \\
\hline & $\begin{array}{l}\text { (Kotseruba, 2007); } \\
\text { (Direct translation into English) }\end{array}$ \\
\hline
\end{tabular}

The explication of word with the lack of vocalism 'древо' does not correspond with the biblical content and is not associated with the designation of branch ancestry.

Sustainable use of the traditions of Old Slavonic origin verbs associated with the development of mobile value in their semantics. Thus, the verb воспрянуть [vospryanut] (rise up) was initially used only in the literal meaning of 'вспрыгиваю, вскакиваю' (juтр ир, јитр оиt). Figurative meaning to 'оживиться, пробудиться к деятельности, ободриться' (to revive, to awaken to the activities, to cheer up) this word gains due to abstract metaphorical thinking and in this meaning of the verb воспрянуть was used in the poetic language of XVIII-XIX centuries. The metaphorical interpretation of the verb rise, defined in Lomonosov's poetry, will be further developed in the linguistic practice of poets and writers of the next decades. And perhaps that is a metaphor used by Lomonosov goes in figurative interpretation of the verb воспрянуть in poetry of A.S. Pushkin, and in particular in his poem « $K$ Чаадаеву» - «Россия вспрянет ото сна»... ("Tо Chaаdaev" - "Russia will rise from sleep" ...) The metaphorical interpretation of the verb воспрянуть, preserving a high stylistic coloration of Lomonosov's usage, became a tradition for the poetic language of the XIX century. In modern Russian language the verb воспрянуть has a special lexical-semantic variant and describes the same type of situation, so combined with the same word, for example: воспрянуть духом (to cheer up, to respire). Due to the fact that the Slavonic word 'воспрянуть' gets in a figurative meaning the expression of citizenship, which expresses a distinct socio-political orientation, it is combined with the words народ, нация (people, nation) and etc.

If we pay attention to sources of examples of using the verb 'воспрянуть' in the language of modern newspapers, most of them are retrieved from the newspaper "Soviet Sport" or columns about sports and sports news in the central Russian media: 
Table 12: Contextual use of the verb "respir"

\begin{tabular}{|l|l|}
\hline Russian & English \\
\hline Может ли народ воспрянуть духом & "Can people cheer up after the \\
после испытаний, что выпали на его & hardships that have fallen to its share?" \\
долю?» & (Roslyakov, 2000); \\
(Roslyakov, 2000); & "After Knyazev's and Sergeev's \\
«После ошибок Князева и дважды & mistakes we could perk up and \\
Сергеева мы смогли воспрянуть & snatched draw" \\
духом и вырвали ничью» & (Belyakov, 2007); \\
(Belyakov, 2007); & (Direct translation into English) \\
\hline
\end{tabular}

These examples demonstrate the modern usage of the verb 'воспрянуть' in the meaning of 'приободриться', 'оживиться', 'подаваться вперед' ('to cheеr ир', 'to revive', 'to fed forward') to describe similar situations in life mainly in sports, in which the spirit of competition is growing, and people, overcoming fatigue and fear, gather all his strength and will in a fist. Description of similar situations also gives rise to the same type of contextual use of the word (Ulukhanov, 2012, p.45) which leads to its stability, i.e., phaseologization.

Some verbs of Old Slavic origin contain in their semantics, and negative emotional: ввергать, влачить, содеять, попирать, посягать (to plunge, to drag, to commit, to trample, to infringe) etc. According to the V.J. Golub (1983), "high vocabulary words, stylistic coloring which is traditionally assigned to specific contexts and situations, is to create elation, pathos in the speech; pathos is connected not only with solemn, laudatory tone of the speech, but also an expression of grief, anger, indignation, etc. This understanding allows high vocabulary to recognize that high tokens may include with its semantics both positive and negative assessment" (Golub 1983 , p. 83). So, some synonymous words are contrasted by rows of emotionalevaluative color in accordance with the stylistic scale: positive / negative with the same subject-logical content. For example, свершить - совершить - содеять (to make - to perform - to commit) and despite the fact that the verb содеять in modern dictionaries is stylistically marked as a word referring to a high vocabulary, it expresses a negative emotional coloring. In the language of contemporary newspapers frequently found typical contexts of the verb ввергнуть in a negative meaning 'привести к чему-либо, втянуть' (to cause anything, to draw down) in such actions and deeds, which would have negative consequences:

Table 13: Contextual use of the verb "plunge"

\begin{tabular}{|l|l|}
\hline Russian & English \\
\hline «И они (эти силы) пре попытку & "And they (the forces) were the \\
разжечь пожар межнациональной & attempt to ignite the fire of ethnic \\
розни, прекрасно осознавая, что & hatred, knowing well that such \\
подобные конфликты на многие & conflicts for many decades could \\
десятилетия могут ввергнуть страну в & plunge the country into chaos, \\
полосу хаоса, трагедии, кровополития» & band, and tragedy of massacre" \\
(Snegirev, 2010). & (Snegirev, 2010). \\
& (Direct translation into English) \\
\hline
\end{tabular}

As a rule, the verb 'ввергнуть' [vvergnut] (to plunge) is used in the context of sociopolitical content and, accordingly, in conjunction with the words of the страна, мир, народ, человечество (country, world, nation, humanity) and others. According to some observations, the word 'ввергнуть' [vvergnut] (to plunge) was recovered in the Russian language from the outdated language in the Great Patriotic War and served as 
a means to create a solemn, pathetic tone (ввергнуть в пучину войны - to plunge into the abyss of war)» (Golub, 1983, p. 84). Multiple contexts of the newspaper texts indicate that the modern use of the word is associated with the creation of a raised tone of speech.

The combination of the verb to overthrow the words with the socio-political semantics президент, законная власть, система, правительство, диктатор, правяший режим (pesident, legitimate power, system, government, dictator, regime) and others due to its traditional context use. However, one of the means of expression of the subjectivity of the journalist in the media today is the use of non-traditional combinations of words in order to individualization of style information message and gain expressive qualities of speech evaluation:

\section{Table 14: Contextual use of the verb "respir"}

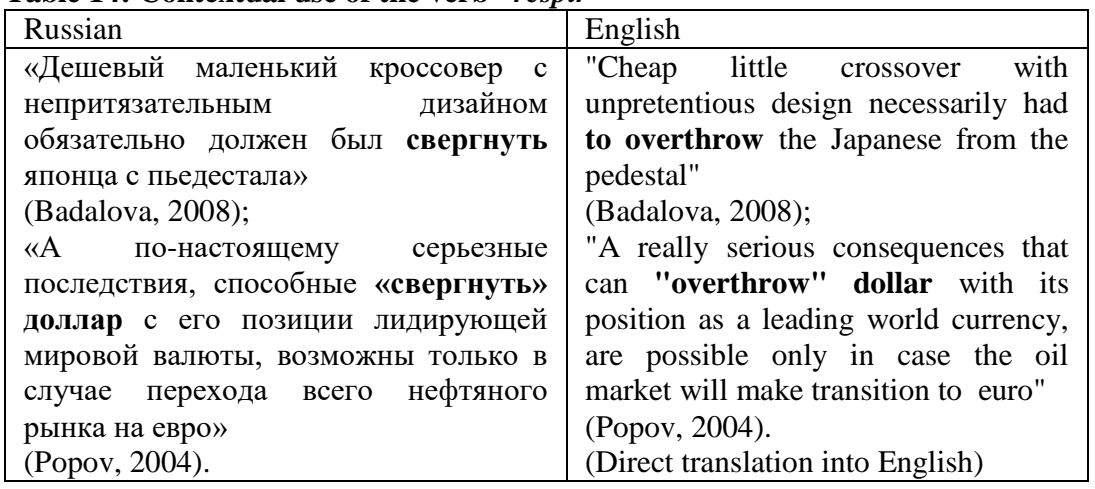

Occasional expression statement fills special semantic information, which is manifested in a subjective vision of reality by the author, is refracted in the creative minds in their own system of values. For example, the Biblical phraseologism 'манна небесная' (manna from heaven) means 'something desirable, it is necessary, rare', and has nothing to do with semolina. According to the biblical myth - it's the food that God sent the Jewish people from the sky every morning, when the "sons of Israel" went into the desert to the promised. In fact, according to botanists, 'манна небесная' - this is just edible lichen that grows in the deserts of Africa and Asia Minor, light gray lumps which are raised up by the wind, and it seems that they fall from the sky. This refers to the combination of the most modern frequency phraseology in speech communication, not only in its original meaning" "что-либо желанное, крайне необходимое, редкое', but in occasional use as a consequence of his metaphorical rethinking on the basis of subjective associations that are more typical for the media language:

\section{Table 15: Contextual use of bible expression "manna from heaven"}

\begin{tabular}{|l|l|}
\hline Russian & English \\
\hline «Для тех, кто проводит бессонные & "For those who spend sleepless nights \\
ночи в борьбе с преступниками, & in the fight against criminals, the \\
появление подобного свидетеля - как & appearance of this witness is like \\
манна небесная». & $\begin{array}{l}\text { manna from heaven." } \\
\text { (Gorshkov, 2006). }\end{array}$ \\
& (Direct translation into English) \\
\hline
\end{tabular}

There idiom is used in a non-traditional sense: 'выгодный поворот дел' (favorable turn of affairs). Despite the fact that occasional use violate phraseological norms enshrined in the dictionary, "they indicate the semantic potential of biblical 
phraseology, which provides its inclusion in the modern conditions of communication, however, if we consider biblicisms in the aspect of mastering by the native speakers, the deviations from the language standard are seen as evidence of the development and exploitation of this fragment of Russian vocabulary and phraseology" (Didkovskaya, 2007, p. 154).

\section{Conclusion}

According to our observations, in newspaper texts Slavonic words describe either a positive or a negative situation that are associated with the formation of the moral concepts that represent a semantic and stylistic originality in the composition of emotional and expressive, evaluative vocabulary. For example, the Church Slavonic vocabulary with positive emotional expressive colouring подвиг, мужество, доблесть, благо, добродетель, благополучие, помощь, благородный, посвятить, воскресить, благословить, воспрянуть, искупить, прозреть (feat, courage, valor, good, virtue, prosperity, help, noble, to devote, to revive, to bless, to rise, to redeem, to see the light) etc. has formed the conceptual sphere of high moral qualities in the minds of the people. Vocabulary with such negative coloring as the вред, срам, безобразие, безумие, тщеславие, брань, измена, враг, коварный, праздный, пресмыкаться, предать, влачить (harm, shame, disgrace, madness, ambition, abuse, betrayal, enemy, treacherous, idle, grovel, to betray, to drag) negatively assessing those or other phenomena, has contributed, in turn, to the formation of the negative qualities of the Russian people.

Functioning of Slavonic words in the language of modern newspapers is characterized, on the one hand, by the actualization of the spiritual aspects of life, on the other by the intensification of the processes of ironic reduction of stylistically marked "high" vocabulary. The frequency of use of Slavonic words in various texts is related to, first of all, the target setting of the writing and the style-forming factors: if in the literary text Slavonic words act as a means of stylization, in the newspaper text - as a means of speech influence. In our view, the trend of use of language means in newspaper texts related to both intra-linguistic factors (mastering of the literary and journalistic traditions, their expressive possibilities of affecting the function), and extra linguistic factors (psychological, social, political, cultural, social and economic). Sociocultural description of ethno-cultural realities in the process of intercultural communication is presented in our article «Axiological characteristics of ethno cultural realities in cross-cultural communication» (Kiynova, Sansyzbayeva \& Akhmetzhanova, 2017).

Thus, the material extracted from the newspaper of subcorpus of RNC, reveals the peculiarities of Slavonic words in modern language newspapers it describes them with diachronic position in synchrony of the language. It is quite logical that the fact that the language of newspapers is most vivid and adequately traced all the dynamic processes taking place in the language, and is reflected in the newspaper "life" of modern society, dictating priorities in the use of language means.

\section{Bibliographic references}

AIF. 2003. Newspaper, April 4. Available online: http://www.aif.ru

AIF. 2008. Newspaper, October 8. Available online: http://www.aif.ru

"AGENCY" NOBODY CANCELS THE SCHEME. 2007. In: RBC Newspaper, November 13, pp, 24-25.

BADALOVA, E. 2008. KUGA for football players of Chelsea Manchester. In newspaper: "Work-7" Newspaper, May 27, pp. 42-43.

BELOV. V.A. 2017. Synonymic relations in language and utterance. In: The Novosibirsk State Pedagogical University Bulletin, vol. 7, n. 6, pp. 263-280, ISSN 2226-3365. 
BELYAKOV, K. 2007. How not to win, conducting 4:0? In: Sovetsky Sport Newspaper, January 17, 34-35.

BIG ACADEMY DICTIONARY OF RUSSIAN. 2005. Moscow: Nauka. ISSN: 5020336629.

BORODINA, T.L. 2017. Phrasal verbs: the problem of misunderstanding or knowledge systematization. In: The Novosibirsk State Pedagogical University Bulletin, vol. 7, n. 4, pp. 186-195, ISSN 2226-3365.

GOLUB, V.J. 1983. Vyisokaya leksika s otritsatelnoy emotsionalnoy otsenkoy. In: Semanticheskiy i funktsionalnyiy aspektyi izucheniya leksiki russkogo yazyika, vol. 1, pp. 76-87. ISBN: 9965-513-82-1.

GORSHKOV, M. 2006. "Transaction with justice" as fight against mafia. In: Komsomolskaya Pravda, September 20, pp. 32-33.

DIDKOVSKAYA V.G. 2007. Frazeologicheskie edinitsyi bibleyskogo soderzhaniya v leksikone sovremennoy yazyikovoy lichnosti. St.Petersburg: Izd-vo RGGU. ISBN: 978-5-8064-1198-4.

DICTIONARY OF RUSSIAN OF THE $11-17^{\mathrm{TH}}$ CENTURIES. 1975. G.A. Bogatova, G.Ya. Romanova, S.G. Barkhudarov (Eds.). Moscow: Nauka. ISBN 5-17-039718-6.

EGORSHEVA, N. 2006. Gubenko was delivered a mat. In: "

Work-7" Newspaper, April 8, pp. 16-17.

EXAMPLE OF WORTHY LEAVING. 2007. In: IZVESTIA Newspaper, December 24, pp. 25-26.

IGNATOV, V. 2005. What party is better? In: "Work-7" Newspaper, March 2, 22-23. GREKOVA, I. 2012. Turning-point. Moscow: Astrel. ISBN: 978-5-271-37347-3.

KAHORINA E.V. 2000. Russkiy yazyik kontsa XX stoletiya (1985-1995). Moscow: Yazyiki russkoy kulturyi. ISBN: 978-5-78590-124-7.

KHRUSTALYOVA, S. 2007. Natalya to Durov was buried near the greatgrandfather". In: Komsomolskaya Pravda Newspaper, November 30, pp. 8-9.

KIYNOVA, Zh.K. - SANSYZBAYEVA, S.K. - AKHMETZHANOVA, A.I. 2017. Axiological characteristics of ethnocultural realities in cross-cultural communication. In: Voprosy Kognitivnoy Lingvistiki, n.3, pp. 142-147. ISSN: 1812-3228.

KOCHUGOV, V. 2011. Believers of Vladivostok will receive two temples. In: Izvestia Newspaper, January 14, pp. 17-18.

KAZAHSTANSKAYA PRAVDA, 2005. Newspaper, September 24. Available online: http://www.kazpravda.kz/

KAZAHSTANSKAYA PRAVDA, 2009. Newspaper, January 15. Available online: http://www.kazpravda.kz/

KOTSERUBA, A. 2007. Who where, and I in library. In: "Work-7" Newspaper, October 19, pp. 7-9.

KOROBOTOV, Ya. 2007. Kostya Jiu's offender was hit in an eye. In: Komsomolskaya Pravda Newspaper, December 11, pp. 14-15.

KOZHIN, A.N. - KRYILOVA, O.A. - ODINTSOV, V.V. 1982. Funktsionalnyie tipyi russkoy rechi. Moscow: Vyisshaya shkola. ISBN: 978-5-905532-04-7.

KUZINA, S. 2006. How "to prisushit" darling. In: Komsomolskaya Pravda Newespaper, June 13, pp. 17-18.

KULTURA, 2009. Newspaper, May 5. Available online: http://portal-kultura.ru/

LVOVA, V. 2006. Grumbler of week: Stars came out to the road. In: Komsomolskaya

Pravda Newspaper, May 12, 25-26.

LYSENKOV, P. 2011. "The Russian classics" we will carry out the first in Kazan? In: Sovetsky Sport Newspaper, February 22, pp. 32-33.

MESHKOV, A. - SNEGIREV, Yu. 2007. As we were treated for alcoholism. In: Komsomolskaya Pravda Newspaper, February 15, pp. 38-39.

MIKHEYEV, V. 2006. Alexey Pushkov. In: "Work-7" Newspaper, June 21, pp. 5-6. MONINA, T.S. 2009. Innovatsionnyie protsessyi v yazyike sovremennoy russkoy gazetyi. Moscow: MAKS Press. ISBN 978-5-317-05151-8. 
RASPUTIN, V. 1998. New profession. In: Sibir, vol. 1, pp. 95-120. ISSN 2410-2520.

ROSLYAKOV, A. 2000. The person who has three homelands. In: "Work-7" Newspaper, May 23, pp. 23-24.

PATRUSHEVA, K. 2010. The Nizhny Novgorod officials have ignored the voice of the people about the general plan. In: Komsomolskaya Pravda Newspaper, June 22, pp. 19-21.

PAVLOV, L. 2007. Kudrin has planned budget revenues for 30 years. In: Komsomolskaya Pravda Newspaper, March 22, pp. 6-7.

PETRUSHOV, I. 2009. It was necessary only to win. In: "Work-7" Newspaper, November 20, pp. 28-29.

PONAMAREV, D. 2007. In the Urals technologies of a research of family trees. In: "The new region 2" Newspaper, November 23, pp. 20-21.

POPOV, A. 2004. The world turns away from dollar. In: RBC daily Newspaper, September 12, pp. 5-6.

RODKIN, A. 2005. The monument to Stalin was wanted to be put on Bow? In: Komsomolskaya Pravda Newspaper, January 19, pp. 14-15.

ROMASHOVA, E. 2005. For first graders of the place there was no "Work-7". In: "Work-7" Newspaper, October 19, pp. 31-33.

SNEGIREV, Yu. 2010. The Russian people are strong the openness. In: Izvestia Newspaper, December 15, pp. 13-14.

ULUKHANOV, I.S. 2012. Istoricheskoe slovoobrazovanie. Istoricheskaya leksikologiya. Moscow: OOO «LEKSRUS». ISBN: 978-5-905532-04-7.

VARSEGOV, N. 2003. Hardly there lives the country of Armenia because of misunderstanding. In: Komsomolskaya Pravda Newspaper, May 12, 9-11.

VARSEGOV, N. 2006. The loving fool will ruin us not AIDS, not cancer, but money! In: Komsomolskaya Pravda Newspaper, June 6, pp. 23-24.

YAKOVLEVA, E.S. 1998. O ponyatii «kulturnaya pamyat» v primenenii k semantike slova. In: Voprosy Jazykoznanija, n. 3, pp. 43-73. ISBN: 0373-658X.

YAMBURG, E. 2005. The people want to know. In: Izvestia Newspaper, December 7, pp. 4-6.

YANCHENKOVA, O. 2008. Start up more buses! In: Komsomolskaya Pravda Newspaper, February 27, pp. 9-10.

ZAOZERSKAYA, A. - HERMANN, J. 2010. The whole country has turned into Maly Kozikhinsky Lane. In: "Work-7" newspaper, December 12, pp, 3-4.

ZHURAVLEV, E. 2000. I grieve for the free permit from trade-union committee. In: "Work-7" Newspaper, October 5, pp. 11-12.

ZORINA, E. 2008. In gardens of Vatican there will be a monument Galilee. In: RIA Novosti Newspaper, March 17, pp. 8-9.

Words: 8075

Characters: 53819 (29,90 standard pages)

Zhanar Kiynova, Prof. D.Sc.

Department of the Russian Philology and World literature

Al Farabi Kazakh National University

Almaty

Kazakhstan

zhkiynova@mail.ru

Sandugash Sansyzbaeva, PhD

Department of the Russian Philology and World literature

Al Farabi Kazakh National University

Almaty

XLinguae, Volume 11, Issue 2, April 2018, ISSN 1337-8384, eISSN 2453-711X 


\section{Kazakhstan}

sk_sansyz@mail.ru

Ainash Ahmetzhanova, PhD

Department of the Russian Philology and World literature

Al Farabi Kazakh National University

Almaty

Kazakhstan

ahmetzhanova.aynash@mail.ru

Dariga Kapasova, PhD

Department of all-university humanitarian disciplines

Nur-Mubarak Egypt University of Islamic Culture.

Almaty

Kazakhstan

assy199@mail.ru

Indira Muratbayeva, $\mathrm{PhD}$

Department of Socio-Cultural Technologies

Saint-Petersburg University of the Humanities and Social Sciences (Almaty branch)

9/11 Chaikovskiy St.

050004 Almaty

Kazakhstan

indiramuratbaeva@mail.ru 